\title{
Perceptions of Online Academics' and Al-Jazeera.net's News Coverage of the Egyptian Political Transformation 2013-2014
}

\author{
MOKHTAR ELARESHI \\ Al Ain University of Science and Technology, United Arab Emirates \\ HATEM ALSRIDI \\ ABDUL-KARIM ZIANI \\ Bahrain University, Bahrain
}

\begin{abstract}
The growth and expansion of the Internet has enabled many people to communicate and engage in different manners and it is easier than ever now to obtain news and information content via different online sittings. However, concerns grow about the effects of misinformation that has been circulated via different online media sites to influence public views. This research was aimed at exploring online academic news users' behaviour and their attitudes towards news information given by Al-Jazeera.net during the Egyptian transformation (2013-2014) in Egypt. Based on an online survey (450 users) and focusgroup interviews (six respondents) with Egyptian academics, the research discussed whether users were aware of the media interest or agenda and how users became informed about the political conflict and the transformation, their perceptions of news sites and their evaluation of information regarding this period. The research confirmed that every media has its own interest or agenda when delivering news content, which might favour one side over another. Users indicated that misinformation was found in different forms and, although others underlined the importance of freely accessing online content, there was concern about the spread of misinformation the morality and credibility of online news.
\end{abstract}

Keywords: Misinformation, Al-Jazeera.net, Mohammed Mursi, Abdel Fattah el-sisi, propaganda, Egyptian elections.

\section{INTRODUCTION}

Shu et al. (2017, p. 22) state that news consumption via social media and the Internet is a "double-edged sword". On the one hand, they are easily accessible and low cost and they enable rapid dissemination of information; on the other hand, they enable the spread of low-quality news with intentional misinformation or false content. Such types of content have impacts on the community, especially when society is polarised and democracy is fragile. Moreover, debates about misinformation, or "fake news", and the media as a vehicle for this, is already an academic concern, with such fears spreading in recent years (EBU, 2018; Shu et al., 2017; Wahutu, 2019). The Arab world, particularly the Middle East, has been a media favourite in terms of news coverage as recent events have unfolded there. Therefore, every media has its own interests and agendas when dealing with different matters. Egypt is often in the news and locals, including many Arabs, love to talk and debate issues and news highlighted by news media. Since 2011, therefore, the country has become a highly polarised society politically, with people more likely 
to be split between pro-military supporters and pro-Muslim Brotherhood supporters (Sanyal, 2015). As a result, some media firms have played roles in shaping these views.

Because of the unstable economic and political situation, massive unemployment and inflation and deteriorating public services, in mid-2013 Egyptians started demonstrating (known as The June 30 Revolution) against the government of President Mohammed Mursi, which was seen not to be acting in the country's interests (Rashdan, 2015; Tambini, 2017). Some incidents in cities such as Aswan, Abasiah and Port Sayyed made the situation even worse. As a result, the "Tamarod" movement ("Rebellion") set up a campaign calling for the resignation of the elected President Mursi and for early presidential elections, which led in June to almost a quarter-of-amillion signatures seemingly collected by Tamarod (Elyachar, 2014, p. 453). Consequently, in July, supported by the Egyptian Army, the Defense Minister, General Abdel Fattah al-sisi, made three announcements: he called for the ousting of the President, for early presidential elections and for a roadmap to complete the state's constitutional institutions. The Supreme Council asked the elected President to respond quickly to the demands of protestors and when he rejected the Army's ultimatum and insisted on managing the demands in "his own way and time", the Army stepped in to oust him from power (Tabaar, 2013, p. 728). In early 2014, the constitution was accepted by the Supreme Court, which revealed the result of the elections, and Abdel Fattah elsisi became President. However, some view this scenario as a "military coup" and see "lack of transparency" in the election process as a "media game" which led to the removal of the elected President and the country returning to military control (Sanyal, 2015; Tabaar, 2013).

The June 30 Revolution was largely considered as a popular occasion that expressed the hopes of many locals. It is called an "online movement", or "youth movement", that enabled the citizens to advocate the January 25 Revolution with fewer offline media being used (Monier \& Ranko, 2013; Rashdan, 2015). The Internet (e.g., social media) has enabled the Egyptians to express their views widely. Following the election of 2014, much misinformation appeared in people's discussions, raising concerns about how information is spread and shared on the Internet, especially in Egypt. According to Statista (2018), the number of internet users in Egypt grew from 34.1 million in 2013 to 36 million in late 2014, meaning that such a segment of the population would find refuge in using the Internet to consume news and information (Al-Rawi, 2017, 2019; Cairoscene, 2014). This research examines perceptions of Egyptian academics of news information given by Al-Jazeera.net during the Egyptian transformation from President Mursi to President el-sisi (between June 2013 and July 2014), the better to understand internet users' experiences with misinformation content and the media agendas concerning Egyptian news.

\section{LITERATURE REVIEW}

Mis/disinformation is not new at all in our world as a threat to democracy and freedom, which raises questions about moral panic concerning fears of the influence of such a phenomenon on communities (EBU, 2018; Sadiku, Eze, \& Musa, 2018; Wahutu, 2019). For instance, the term was recently used by different news sources covering the controversies that followed the US presidential election of 2016) (Carson, 2018; see e.g., Silverman \& Singer-Vine, 2016), the UK Brexit campaign (2016) and other political events in Europe (Briant, 2018) and elsewhere. The increased use of online news media has raised concerns about online- 
content trustworthiness (Farhi, 2014; Shu et al., 2017). In fact, Sadiku et al. (2018) indicate that "fake news" is a type of misinformation or biased news (they call it propaganda) and has been known for decades (see also Briant, 2018; Wahutu, 2019; Wardle, 2017). Alcott and Gentzkow (2017, p. 213) define "fake news" as "articles that are intentionally and verifiably false, and could mislead readers... It also includes many articles that originate on satirical websites but could be misunderstood as factual". This now presents huge challenges for the public and a need for them to be educated in terms of media literacy to enable them to understand media agendas and interests.

In the Arab media, the media agenda is affected by political orientation as many news providers are politicised and monitored by governmental bodies (Buccianti \& el-Richani, 2015; Miladi, 2006; Sanyal, 2015). Such interest and agenda, even among some leading Pan-Arab TV services (e.g., Al-Jazeera and Al-Arabiya), has seen them being used as a "propaganda mechanism" to limit the availability of facts, redefine contexts, mask the transparency of political motivations (Jones, 2019) and produce news information that might not fulfill their audiences' interests, especially during and after the Arab uprisings of 2011 (Khatib, 2012; Lynch, 2015; Mejalli, 2019). For example, Buccianti and el-Richani (2015) state that news media in the Arab world are mainly owned by political and commercial bodies and are heavily influenced by the political stance of the channels' owners, especially in times of war and conflict. Khatib (2012, p.181) states that Arab media frequently "proxy" platforms to promote rivalries between Arab nations and their motive "is the propagation of messages favourable to the self while discrediting others". Arthur (1980, p.121) mentions that, in the UK, Winston Churchill said that "in wartime, truth is so precious that she should always be attended by a bodyguard of lies". Therefore, mainstream media and online media are shaping news content based on their interests and are increasingly used in times of conflict and political instability. This clearly raises concerns about the ethical standards of news media, both online and offline; as Boyd (2017) says, "the news media have become a pawn in a big chess game of an information war".

\section{Online Media and Viewers' Perceptions}

The increased use of the Internet in the Arab world has attracted the majority of news organisations (e.g., Al-Jazeera) to go online to engage with their viewers and to "satisfy" their demands (Al-Rawi, 2017), including their demands for political news. Moreover, it is claimed that Al-Jazeera, via its website, began closely covering the Egyptian political situation even before the 2010 uprising and was heavily involved in the last Egyptian political transformation, claiming to have a good relationship with the Muslim Brotherhood organisation (Hroub, 2011; Trager, 2017). Such a claim is seen to "serve Qatar's foreign" interests when dealing with foreign news (Mejalli, 2019, p. 25). This proves that the channel itself, like many others, has its interest and agenda when providing news and information, which might not be accurate.

Sadiku et al. (2018, p.187) highlight four different types of misinformation in the online world that attract information traffic. These are "Clikbit" (known as clickbait) news/information, which refers to news that is created to generate clicks to increase ad revenue (see (also see Tambini, 2017), such as sugar causes cancer); "Opinion", which refers to information in a writer's commentary that is intended to influence the reader; "Propaganda", which has been well known over decades as the promotion of certain agendas and interests; and "Humour", which refers to 
the news and information provided for the purposes of giving the public entertainment or joy. Allcott and Gentzkow (2017, p. 217) add two main motivations for producing such information: "pecuniary" and "ideology". Boyd-Barrett (2016, p. 30) indicates that governments use "the media to whip up patriotic fervour, boost support for the authorities, and marginalize and/or ridicule dissent and dissenters when these are not actively criminalized by the State".

Al-Jazeera, arguably well-known as a channel since 1996, has become a popular, credible news provider for both Arabs and non-Arabs (Al-Rawi, 2017; Fahmy \& Al-Emad, 2011). In fact, since launching its news site in 2001, it has experienced incredible development and now reaches users worldwide (Fahmy \& Al-Emad, 2011). Because of this, however, it has caused a great deal of diplomatic tension between Arabs and non-Arabs in countries such as the US, Jordan, Bahrain, Saudi Arabia, Libya and Egypt (Al-Rawi, 2017; Al Jazeera, 2015), with some nations either withdrawing or downgrading their diplomatic relations and some banning it and blocking its website (Jones, 2019; Williams, 2014). Regarding Egypt, Al-Jazeera might be perceived as supporting the Muslim Brotherhood party and being heavily involved in Egyptian politics (Al-Rawi, 2017; Hroub, 2011; Jones, 2019). For example, it has allowed the pro-party spiritual leader, Shaikh Yousef al-Qaradawi, to comment, evaluate and challenge Egyptian promilitary supporters (Schapals, 2018; Trager, 2017). Al-Rawi (2017) mentions that the channel sided with the pro-Muslim Brotherhood over other parties, forcing many journalists to resign from the channel in July 2013 over slanted coverage. Al-Qaradawi often challenges some Arab political sensitivities which have led to serious diplomatic crises, resulting in a political rift that was amended after al-Qaradawi's Al-Jazeera talk-show was canceled (Al-Rawi, 2017, p. 28).

Furthermore, Saudi officials, defending their own interests, often complain about AlJazeera being used by Qatar as a political tool and about the channel's support for radical movements in Syria, Libya and Egypt (Farhi, 2014). Meanwhile, the Saudi platform, Al-Arabiya, is closer to pro-Western governments such as Jordan, Egypt and Saudi Arabia itself (Abdullah \& Elareshi, 2015; Ziani, Fahmy, Al-Jaber, \& Elareshi, 2014). Both platforms have demonstrated an interest in providing international live news (e.g., coverage of political affairs, protests), which makes them vital sources of information (Abdullah \& Elareshi, 2015; Sultan, 2013). Johnson and Fahmy (2008) state that Al-Jazeera is powerful enough to influence many Arab mainstream media outlets because of its news and information qualities, such as live coverage of news, its sophisticated programmes and the way in which it deals with news information across the world (El-Nawawy, 2003). However, some have blamed Al-Jazeera for causing instability and for having different agendas in countries such as Syria, Yemen and Libya, which has led to questions over its reliability and trustworthiness (Al-Rawi, 2017; Bar'el, 2016; Mejalli, 2019). For example, AlJazeera was criticised for slanted coverage of the January 2011 uprising in Egypt, while joining soft-media coverage in opposing the subsequent uprising in Bahrain (Elareshi, 2013; Hroub, 2011; Trager, 2017). As the Alquds Arabi newspaper writer, Bassam Badarin, wrote, "when I watch Aljazeera I feel sorry for General Sisi [...] when I watch al-Arabiya I feel sorry for Ikhwan (Muslim Brotherhood party) and when I watch the Jordanian TV I feel sorry for myself", (cited in Shehabat, 2015, p. 38).

With the widespread use of the Internet, some Arab regions have become worried about their long-term stability, especially after the scenario of 2011, which caused civil wars to erupt in Syria and Libya, with online media considered to play a vital role in supporting such movements 
(Abdullah \& Elareshi, 2015; Mejalli, 2019; Sultan, 2013). In fact, Arabs know that, from its beginning, Al Jazeera was very distinctive, attracting viewers from all over the world (Dennis, Martin, \& Wood, 2016; Elareshi \& Gunter, 2012b; Johnson \& Fahmy, 2008), and if people have trust in one medium, they are more likely to consume its productions (Melican \& Dixon, 2008; Ruggiero, 2000; Tsfati \& Cappella, 2003).

This might be why, according to the Selective Theory (ST), users tend to look for consistency when contradictory information appears, affecting their values and beliefs. They are more likely to find information with which they would agree, as Zillmann and Bryant (1985) and Melican and Dixon (2008) indicate. New media usually provide what is called an "amplification in selectivity", which means that users predominantly share news information that reflects their own opinions and avoid information that conflicts with their own views (Brundidge \& Rice, 2008, p.151). Users also tend to select the information that accords with their pre-existing beliefs and follow those who support their views, creating what are called "echo-chambers", especially in matters related to politics, as Yang et al. (2017, p. 22) indicate. This means that, as some argue, people follow news organisations that attempt to provide what they want to consume (Elareshi and Matthews, 2013). This was particularly true after the spread of pan-Arab satellite TV news broadcasting and the Internet, which helped the rise of public awareness and formed audiences containing like-minded users who followed these platforms and had growing expectations from such media (Elshitawi, 2005; Gunter, 1985). This has led to audiences consuming and believing any information provided by these media, especially if they are perceived as a "credible source" (Elareshi \& Gunter, 2012a).

The observations here are that we live in a world in which different institutions and societies have become dependent on media outlets, especially in the Arab world. This perhaps links to the term mediatisation, which is defined by Hjarvard (2013, p. 17) as the way in which society and culture have become increasingly dependent on the media and their logic. The media have become increasingly influential and become integrated - directly or indirectly - in different spheres of society (Mejalli, 2019) (in our case, Al-Jazeera.net in Egypt). Because Al-Jazeera (both online/offline) has contributed to Arab political awareness and transformation, it might be perceived as a tool related to supporting some public opinions (Elareshi, 2013; Hroub, 2011) and as a "credible source of news" (Zayani, 2005, p. 17). Therefore, the research questions are formed as follows:

RQ1: How has online academics perceived news information from Al-Jazeera.net?

RQ2: How do they evaluate the news content provided by Al-Jazeera.net?

RQ3: Has the Al-Jazeera.net news content changed during the Egyptian political transformation.

If so, in what way?

\section{METHODOLOGY}

Survey

a. Participants

Data analysed (Table 1) were collected from online Egyptian academics (450) in nine Media and Communication departments in both public and private universities: The American University in 
Cairo (private); Cairo University (public); Beni Suef University (public); The Canadian University (private); The German University in Cairo (private); The October 6 University (private); The Pharos University in Alexandria (private); University of South Valley (public); and the University of Misr for Science and Technology (private). Such activists are important because such online academics are already professionals in their media industry and are more aware of how news is produced and delivered, particularly in terms of highlighting media interests. They are online activists and better at analysing the role of online content and at evaluating it.

\begin{tabular}{lcc}
\multicolumn{3}{c}{ Table 1: The sociodemographic features } \\
\hline Items & $\mathbf{N}$ & $\mathbf{0 . 0 \%}$ \\
\hline Gender & 309 & 73.9 \\
Male & 109 & 26.1 \\
Female & & \\
Age & 79 & 18.9 \\
$26-35$ & 144 & 34.4 \\
$36-45$ & 100 & 23.9 \\
$46-55$ & 68 & 16.3 \\
$56-65$ & 27 & 6.5 \\
>66 & & \\
Education Rank & 21 & 5.0 \\
Professor & 66 & 15.8 \\
Asso. Professor & 60 & 21.6 \\
Ass. Professor & 114 & 27.3 \\
Lecturer & 127 & 30.5 \\
Ass. Lecturer & & \\
Specialism & 86 & 20.6 \\
Journalism & 115 & 27.5 \\
PR and Ads & 96 & 23.0 \\
Radio \& TV & 120 & 28.8 \\
Online Media & & \\
Residence & 296 & 70.8 \\
Urban & 122 & 29.2 \\
\hline Rural & &
\end{tabular}

\section{b. Procedures / Measures}

Given the time frame, the costs involved and the situation in Egypt while conducting this data gathering (February-March 2018), this study used an online survey that was randomly sent through an email message to a sample of all the above universities, kindly requesting them to answer 11 questions (six questions related to perception and evaluation of news topics using a Likert scale and other open/closed-ended questions as the primary form of measurement, with another five questions asking about sociodemographic information). Given the sensitivity of the topic, however, we were aware of the possibility of political orientation and of the need to reduce bias in our participants' responses. First, therefore, we tried to design non-suggestive leading questions; second, participants were asked to be as honest as possible (Supplement 1); and finally, all the provided answers were statistically tested using Cronbach's Alpha test and Intraclass Correlation Coefficient $(0.899, \mathrm{n}=450)$. 
Before proceeding, it should be noted that the data were gathered through googlesurvey.com and, because of this, the generalisability and the findings are limited only to the respondents. Having studied only academics, this can be seen as a potential bias and as problematic and this is acknowledged. Therefore, the survey is measuring only participants' opinions/perceptions and these might not be the objective reality. The survey was voluntarily completed in those Egyptian universities mentioned above at a time of instability and this might affect participants' views. The survey was designed in Arabic (the respondents' main language) and the questions were reviewed several times to ensure that they were linguistically clear.

\section{Focus Group}

The focus group was conducted (in Arabic) with six Egyptian academics (Supplement 2) from the same above universities, who voluntarily accepted to be interviewed further. These were all males: one full journalism professor (R1), three associate professors (R2, R3, R4) (in Online Media, Journalism and PR respectively) and two assistant professors (R5, R6) (Journalism, Radio and TV respectively). Their experience ranged from five years to 29 years. The interview was semistructured, allowing participants to express their opinions freely as much as they would choose to do so (Schapals, 2018) and to discuss matters at their convenience.

Four main axes were given to the interviewees for discussion in terms of highlighting news content provided by Al-Jazeera.net (during 2013-2014). Bearing in mind that discussing matters openly in Egypt is often problematic and that there is a social-desirability bias (Hargittai \& Karaoglu, 2018) as participants may not answer the questions accurately as certain topics might be affected by political orientation or ideological views, and maybe self-censored (such as Egypt vs. Al-Jazeera; pro-Mursi vs. pro-el-sisi), the authors recognised this as a challenge. Therefore, the authors assured all participants that the data gathered would only be used for academic purposes and that no personal information would be disclosed. Participants were asked nonsuggestive leading questions on matters such as (1) the concept of misinformation content (its goals, aims, effects on media credibility); (2) Arabic e-journalism and misinformation (its uses, editorial policies, and journalistic ethical standards); (3) the relationship between Egypt and AlJazeera (during 2013-2014); and (4) the impact of Al-Jazeera.net coverage on the political, security and economic situation in Egypt. To examine the focus-group content, the study ran MAXQDA, unique software that helped to collect, organise, analyse and visualise qualitative and mixed research data.

\section{a. Survey Results}

\section{FINDINGS}

\section{News Content}

When participants were asked how they perceived news information about Egypt during the aforementioned period, $63 \%$ of them said that they perceived some of Al-Jazeera.net's news content to be "less accurate" regarding the country's news, while the rest (31\%) said that they "did not know" or that the news was "very accurate" (6\%). The findings showed that participants were aware of some media interests and news content delivered about their country. This may 
be why some Arab nations have been worried about online news that might affect the status quo and political stability, especially after the 2011 uprisings (Al-Rawi, 2017; Trager, 2017).

Surveyed participants were asked, more specifically, about news content covering the period from June 302013 to July 32014 . Interestingly, one-third (35\%) of participants considered that the network had different interests, or might "manipulate" (27\%) the locals during this period, while others (14\%) felt that the network was "very objective", or "partially objective" $(10 \%)$, when delivering such information.

Those who perceived the network as having different interests and agendas were further asked to identify the types and scopes used to post such information: photos/images (89\%), videos/clips (82\%), references to other news sources (80\%), applied hyperlinks $(50 \%)$, news stories used (43\%), news context (36\%), comment on news issues (38\%), social-media platforms used $(16 \%)$ and selected political figures (14\%) were all emphasised. For the scopes, the news information could be found in "security and military news" (60\%), "political figures/news" (59\%), "sports news" (39\%), "financial news" (26\%), "cultures" (24\%) and "social events" (21\%). These results revealed the ability of participants (not surprisingly, given their professional level) to spot the types and scopes of information that can be posted in an online format. Interestingly, use of images and videos, or references to other news sources by any platforms (e.g., Al-Jazeera.net), are cleaver techniques that would intentionally divert/direct users' views. Using such techniques (e.g., images) during the crisis in Egypt (2013-2014) would have an impact on users' perceptions and their understanding of their situation. Images can serve to attract attention and are often processed before reading the full test, as misuse of images can lead to action being taken. These findings confirmed pervious research indicating the spread of false content through online sittings (EBU, 2018; Silverman \& Singer-Vine, 2016; Wahutu, 2019), especially social-media sites, since the Arab uprisings of 2011 and also globally (e.g., during the 2016 US presidential elections) (Shu et al., 2017).

Further analysis was run to explore how participants evaluated any news-content interests concerning Egypt. Six general items associated with such information were given and measured on a five-point Likert scale where "strongly agree" (SA) = 1 and "strongly disagree" (SD) $=5$. Table 2 summarises the results.

\begin{tabular}{lccc}
\multicolumn{4}{c}{ Table 2: News-content awareness about Egypt $(\mathrm{n}=417)$} \\
\multicolumn{1}{c}{ Items } & SA & DK & SD \\
\hline To support the MB party & $66.9 \%$ & $8.2 \%$ & $25.0 \%$ \\
To affect the presidential elections & $64.7 \%$ & $9.4 \%$ & $25.9 \%$ \\
To manipulate the internal image of Egypt & $62.9 \%$ & $11.5 \%$ & $25.6 \%$ \\
To manipulate the external image of Egypt & $62.8 \%$ & $11.5 \%$ & $25.7 \%$ \\
Counterfeiting news is known on online media & $61.9 \%$ & $11.3 \%$ & $26.9 \%$ \\
The network does post misinformation news & $60.9 \%$ & $12.2 \%$ & $26.9 \%$ \\
\hline
\end{tabular}

The results indicated that most participants were somehow in agreement that some news content about the situation in Egypt was affected by news interests. As a popular platform, AlJazeera.net was able to contribute to the polarisation in Egypt and elsewhere by providing some information that would lead the users to take some actions in different formats: supporting the Muslim Brotherhood party, affecting the presidential elections, or manipulating the internal and 
external image of Egypt. The result indicated that the news coverage of Egypt was not balanced and that this had been the case since 2011, as Hroub (2011) argues. This is unsurprising as AlJazeera is already known for its support of some ideological and political views in the Arab world (Lynch, 2015) which reflect its interests and agenda (Ziani, Elareshi, \& Al-Jaber, 2017), concerning events in Syria, Egypt and Libya, but not in Bahrain (Mejalli, 2019).

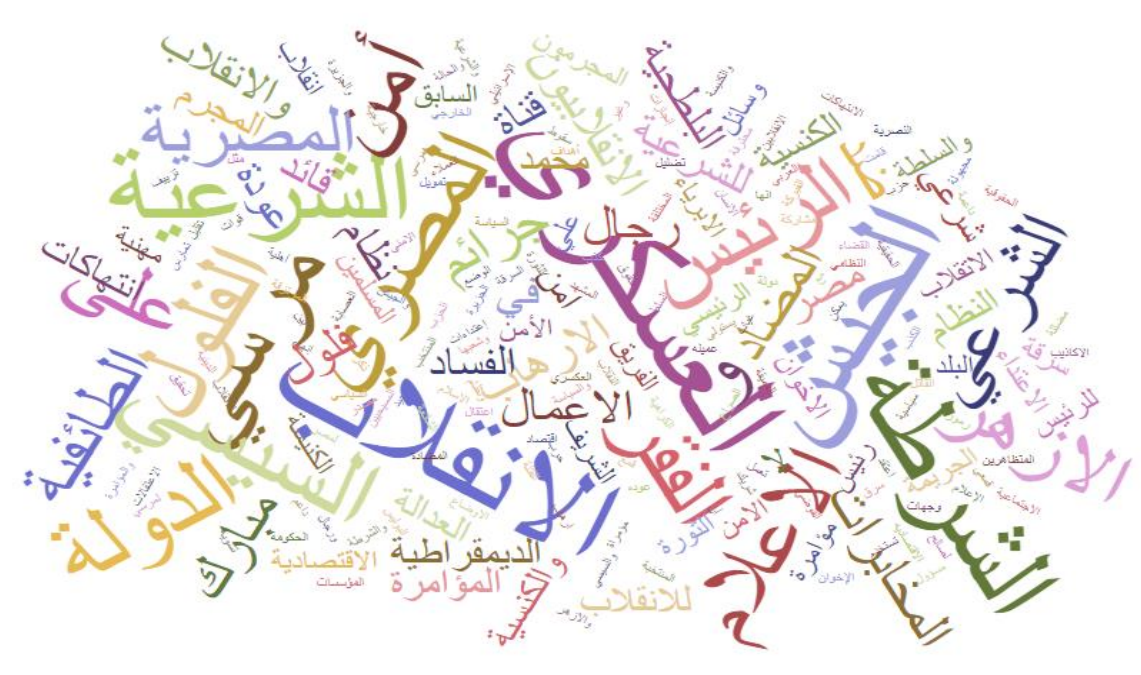

Figure 1: The most frequently mentioned words/phrases regarding information content about Egypt

An open-ended question asked the participants to indicate/highlight three keywords/phrases that they could use to describe the online information delivered about Egypt (Figure 1). The word-cloud (via MAXQDA software) frequency determined the most frequent keywords used in depicting news about Egypt. These were: (العسكري) "army/military" (32\%); (العسكري الانقلاب) "army coup" (17\%); (الثر عي الرئيس) "Mursi" and (the legitimate President" (16\%); and (الثرطة) "the police" and (الامن) "security" (14\%). Less frequently used words or phrases were: (السيسي) "al-sisi" (8\%); (المصري الإعلام) "the Egyptian mainstream media" (6\%); and (الفقر)) "poverty" (5\%). Al-Jazeera.net seemed to have an interest in providing more information about some Egyptian sovereign institutions, such as the army and other security bodies, and in supporting President Mursi, with fewer mentions of al-sisi. This confirmed the role of online media, showing how they support some views based on their interests and how they highlight the political struggle in terms of getting the public's attention, resulting in the possibility that the network might be perceived as being unbalanced (Rashdan, 2015; Bar'el, 2016). Tsfati and Cappella (2003, p. 506) concluded that there was scepticism about such news, as it was affected by how journalists perceive it, and a belief that journalists "are not [always] fair and objective in their reports, that they do not always tell the whole story, and that they would sacrifice accuracy and precision for personal and commercial gains".

\section{b. Focus Group}

The Concept of Misinformation News

To identify such information, and how participants perceive it in terms of objectives and effects, our interviewees were asked about the concept of misinformation in general. Most of their views 
were that misinformation was news-story content that was fabricated, politically directed with ideological views, or professionally delineated to harm others or blur the truth. Misinformation was likely to be different from rumours, which usually had a social dimension and could be spread without knowledge of their source, whereas misinformation reports had an institutional interest because they were strategically issued.

Information is called news when it is published by media institutions (e.g., CNN or $\mathrm{BBC}$ ) and, if it turns out to be a rumour, it is considered as false news. Rumours are confined to the social sphere, only among people, without being usually published in the media (R1). The concept refers to fabricated news that is strategically launched by a particular state, group or individual in order to harm others. This news is used as a way of blurring the truth, of defaming people, sometimes for ideological interest or creating chaos (R2).

The participants also mentioned that such news had become increasingly frequent and complex via the Internet and social media (Calabresi, 2017; Hargittai \& Karaoglu, 2018). Online media were not independent and were fuelled by content that had a vital impact on public views, but at the same time contributed significantly to the dissemination of false news, negatively affecting the platform's credibility in the long term (Al-Rawi, 2017; Farhi, 2014; Wahutu, 2019).

The spread of misinformation via online media would have left a negative reputation on how the media is perceived in term(s) of credibility. It is hard now to control such (a) phenomenon and we all know that even the most prominent companies, such as Twitter or Facebook, are working to monitor information traffic on their sites to protect the public interest (R5).

Fairness and objectivity are crucial when news content is delivered by any media, as their job is to protect the public interest (Tsfati \& Cappella, 2003). The participants highlighted several reasons behind delivering such news, whether published through online or offline media. These reasons were mainly concerned with "political propaganda", usually linked to the particular media's interest and its aims in terms of influencing the public.

Perhaps the purposes of publishing false news could have (a) media agenda and (the desire) to promote/enhance a certain political view; create chaotic (conditions in the country); or influence the public for ideological gain (R2). It is also to put pressure on officials to accept/deny such news and to provide accurate information (in case of false news), or just for joy and entertainment. Such news, therefore, has multiple purposes (R5).

Some participants highlighted the strategic objectives of media interests, referring to them as "fake wars". Online platforms have worked in tandem with campaigners and street protests to shape political views in Egypt (Tambini, 2017). For example, participants indicated that many false news reports were manufactured as part of a strategy of creating problems and 
keeping people in a busy circle for two reasons: "self-weakening" and to gain "hegemony over them". Thus, media could be used intensively in support of such claims, as one participant indicated:

Today there are two strategies for growth: self-growth and stopping the other in doing so. Such media platforms work intently to stop self-growth by creating problems to last for long and stopping people to go forward or grow. The media here (online/offline) can contribute greatly to this (R6).

Most interviewees agreed that, during 2013-2014, Al-Jazeera.net had its interests in its provision of news delivered in a professional manner (Hroub, 2011). They considered that some of its news content affected the locals and that either its journalists were not objective in their coverage, or they were slanted in their views. As one said: "[news] ... sometimes it's only partially true - but politics is a dirty game" (R6). Meanwhile, some argued that the network was very professional in handling news content in three ways: (1) posting completely fabricated news; (2) framing the news (highlighting a single part of the story); and (3) modifying the story to fit the network's interests.

Three types of news can be highlighted on Al-Jazeera.net production: (1) completely fabricated news; (2) framing news; and (3) modifying news (R2). AlJazeera.net is (a) very popular platform. Although it pushes the boundaries of information in the Arab world and elsewhere, I believe, since its inception, it creates confusion and political agendas (R3).

\section{Arabic e-Journalism and Misinformation}

People increasingly depend on Internet content for different matters, including political awareness. However, the Internet in the Arab world is still under development and there may be a legislative vacuum regarding its regulation. Such lack of legislation may affect the quality of information produced and lead to the production of information that might not fit with the public interest, such as false news. Most Arab governments are worried about the spread of information via online sittings and, therefore, they are closely monitoring such flows and have blocked several online sites such as Al-Jazeera.net (Mejalli, 2019).

It is not easy to ignore the role of media in disseminating different news to influence the public opinion. We all know that there are organised and strategical institutions and perhaps individuals work(ing) to influence the public through emedia. These groups are important source for news and, therefore, are monitored in most Arab countries (R1). 
Such use of the Internet has emerged as fertile soil for producing false news. One respondent believes that online fabricated news is used in two basic areas: the political field, including the struggle for power (e.g., seeking intellectual, religious, cultural and economic influence); and the personal field, including manipulation of the public celebration of news.

Two types of fabricated news can be highlighted and the goal is to provoke more distribution, celebrities in art, sports and money, the struggle for power, political or personal distortion (R4).

Some believe that the practice of posting such information is done through fake accounts (bots) (Allcott \& Gentzkow, 2017; Calabresi, 2017) that create fabricated news and contribute to affecting public figures and manipulating public opinion (Allcott \& Gentzkow, 2017). Consequently, such practices have nothing to do with established journalistic ethics.

Fake accounts, or bots, are common now. They are used to incite protest, creating fake news, manipulating public opinion, affecting political campaigns, etc. (R3). These practices go beyond the ethics of journalism, but rather they damage the human right to truthful information, which made many researchers alert journalists to be fair when covering news and not to be drawn into (a) suspicious position (R4).

\section{Al-Jazeera News and Egypt (2013-2014)}

Since its inception, many Egyptians, like others, followed Al-Jazeera and were impressed with its news and programmes, even those delivered by Egyptian presenters such as Ahmed Mansour, Ayman Azzam, Yosri Fouda and Mohammed Haykal. However, the network has caused different diplomatic tensions between the network and the government. During this period, the relationship between the two was not smooth. For example, the network was blamed for playing a role in all the country's uprisings (since 2010) (Salleh, 2014). There was a shift in the political position in Qatar towards Egypt after June 30, the date that President Mohamed Mursi was ousted. On this basis, the network has also changed to coincide with the official Qatari interests, with Qatar supporting the legitimacy of the BM party (Al-Rawi, 2017; Trager, 2017). However, such a change was mentioned by the participants.

If the political situation in Qatar before June 30 is different from what comes after it, we are talking about a shift in media interest for Al-Jazeera according to the transformation (R6). Before July 30, Al-Jazeera was speaking on behalf of a specific political faction $[\mathrm{MB}]$ and after that its purposes were noted and identified by the majority of the Egyptians (R4). 
This is why the network attracted a barrage of criticism from Arab and non-Arab governments and a wave of complaints hit Qatar at a high level, exemplified in the blockade of 2017, as a result of Qatar supporting ideological and radical groups (Jones, 2019) and becoming a representative for all Islamic movements in Arab and non-Arab countries (Al-Rawi, 2017; Jones, 2019). As for official affairs, after the suspension of Al-Jazeera in Egypt in 2014, news turned into a "media war" with "political propaganda" aimed at smearing the reputation of the new government in Egypt (Rashdan, 2015). This raised moral panic concerning the influence of this phenomenon on people's views.

Since the channel's suspension in Egypt, the channel shifted its objectivities in its media treatment of the Egyptian situation (R5). The channel has clearly gone beyond its professional standards and started to assault the nation with "media war" and "propaganda war", using all types of propaganda influence and distorting the new system's reputation (R3).

The network had a strong effect at the beginning, especially during the Rabaa protest ("lietisam Rabiea") on June 28, but this effect gradually faded as the local authorities and media were somehow able to take some lead in terms of deception about Egypt. For example, the local authorities controlled information flow (Farhi, 2014).

As I recall, (during) the days of the Rabaa protest, that the network had a great impact on the locals' views, but afterwards, its impact reduced on the Egyptians because of the attempts made by various local authorities and media to such coverage (R1).

\section{The Impact of the Network's Coverage on Egypt}

Overall, the network has arguably succeeded in gaining the minds and hearts of many Arabs and non-Arabs by the way it handles news and information (Johnson \& Fahmy, 2010). However, since the wave of Arab uprisings (2011), much news content delivered by different media (offline/online) has seemed slanted in its outlook (e.g., its coverage of Egypt compared with its coverage of Bahrain) (Al-Rawi, 2017; Bar'el, 2016). However, such involvement seemed not to affect the country's economy as the participants emphasised that the local economy increased its foreign-currency reserves after June 30. In addition, the level of public awareness also increased with the discovery of the practices of delivering such misinformation.

The Egyptian economy was not really affected by the network's news, as evidence shown an increased local reserve after June 30 from 36 billion to 48 billion Egyptian pound(s), and if we continue in this way, we would be a big figure in the global economy (R4). The network has no impact on the locals because they are aware enough to understand the media context and game (R5). 


\section{DISCUSSION}

An online survey and in-depth interview were run to investigate the perceptions of online news users, and how the Egyptian political transformation (2013-2014) was covered by Al-Jazeera.net, through asking Egyptian academics. In response to RQ1, evidence emerged that some online news content contained some information that may not be accurate and was affected by media interests, especially during times of unrest (Allcott \& Gentzkow, 2017; Shu et al., 2017; Trager, 2017). In the digital age, there has been a huge growth in use of online platforms by many Arab activists over the past decade or so (Dennis, Martin, \& Hassan, 2019; Jones, 2019; Ziani \& Elareshi, 2016). These platforms have allowed users and activists (e.g., Egyptians) to participate in events and access news information. However, the quality of such news is questioned as many can challenge its purposes and intention (Allcott \& Gentzkow, 2017; Elareshi \& Gunter, 2012a) because this information is constructed in such a credible way that it may play a role in manipulating people's perceptions and beliefs, as reported by Salem (2017), especially in Egypt where it is reported that people get access to news through different platforms, including AlJazeera.net (Al-Rawi, 2017; Dennis et al., 2019, 2016). Participants might perceive some news information regarding events in Egypt to be affected by media interest via 24/7 Egyptian news coverage and Al-Jazeera.net, which played a vital role in providing such news (using images, clips and news sources) about the political situation. As a result, some news was even produced by online activists (Lynch, 2015; Monier \& Ranko, 2013).

In response to RQ2, which asked how academics evaluated and became more aware of news content, there was clear recent disagreement between the network (representing Qatar) and most of the Egyptians (at least the authorities) over several allegations and problems (Cherkaoui, 2014). Participants were able to highlight the interest of being pro-MB (Shehabat, 2015) and of interference with local issues (Salleh, 2014; Sultan, 2013). This highlights media intention and interests. Participants emphasised that the "media war" and "political propaganda" were used at this time to manipulate public views regarding current affairs.

Furthermore, our participants seemed to understand how misinformation gathers speed online and affects the real world, especially via the use of social bots. Such news is likely to be used for political, religious and economic gain (Calabresi, 2017). This leads to the need for clear legislation to manage the online context and perhaps to make people more aware when reading online content and to train online journalists to be more careful and to act with more independence with the types of information that they display on news sites (Briant, 2018).

Given the complexity of the situation in Egypt (2013-2014), any news information could divert/shift people's views, debates and understanding of their situation (RQ3). The network, in a professional manner, was able to deliver news information that might be changed over time and that might support one side over another (e.g., the campaigns for Mursi vs. el-sisi) (Mejalli, 2019; Rashdan, 2015). For example, the symbiotic relationship between the network and MB has been clearly observed for a long time (Mejalli, 2019; Shehabat, 2015). Cherkaoui (2014, p. 26) states that Al-Jazeera's news coverage of the Arab uprisings (2011) was seen as "a clear deviation from its early standards to provide balanced news". Some have questioned its "truthfulness" in supporting some events (in Egypt and Libya), while clearly ignoring others (in Oman and Bahrain). Its position in terms of what was going on in Egypt was, for example, to call the military's ousting of Mursi a "coup" and, therefore, the network was seen as an enemy in parts of Egypt, leading 
the Egyptian government to harass its journalists and its operations from within Egypt (Farhi, 2014).

The network was also blamed for interfering with Egyptian affairs, and attempting to influence the public's views of their government, even before 2013 (Buccianti \& el-Richani, 2015; Shehabat, 2015). The relationship between both might be described as unstable (Bar'el, 2016; Trager, 2017). As a result, Al-Jazeera's main office in Cairo was closed as a result of its strong positive sentiment and support for Mursi, as mentioned by Farhi (2014) and Al-Rawi (2017). Arguably, however, Egyptian users seemed to favour following Al-Jazeera.net's news if they were pro-Mursi, as such views were often expressed on the network. Such a position is explained by the ST assumption that people are more likely to follow information that they would agree with (Zillmann \& Bryant, 1985). In terms of expressing such views, Al-Jazeera.net is already known for allowing like-minded people to share news and comment on the internal politics and issues regarding the conflict (Al-Rawi, 2017; BBC, 2013).

\section{CONCLUSION}

Since the Arab uprisings of 2011, news information through news sites and the Internet have become important elements in mobilising and supporting online activists to encourage protests in several Arab countries (Arafa \& Armstrong, 2015; Barnes, 2013; Lynch, 2015; Mejalli, 2019). The term "misinformation" refers to those stories that are intended to be false for different reasons and such information might be highlighted during conflicts such as those occurring in Egypt since 2011. Such stories might find a way through online sittings (e.g., social media) (Wahutu, 2019) to divert and affect users' views and beliefs or to increase readership and Internet click revenue, as Sadiku et al. (2018) indicate. This is why current-affairs coverage in any country is seen as being core to the public in terms of informing them about what is going around them by offering and providing different news with pluralistic views and providing room for "alternative views", as Cherkaoui (2014) indicates. To fulfil this role, independent public media services (national/international), or "alternative media", are crucial. At the same time, however, attempts by news media to meet their users' desires can even sometime lead to the provision of news satire.

To sum up, although our study attempted to show how online news content delivered by Al-Jazeera.net is perceived, the results should be understood in light of its limitations. For example, the period analysed in this research witnessed ongoing discussion about misinformation provided by different news media. Our respondents (all Egyptian) could have misunderstood our questions and been influenced by their cultural ties and their connections to their country, which might respond supporting one view over another. Indeed, further studies of other sociodemographic sectors are needed in terms of a wider variety of media. 


\section{BIODATA}

Mokhtar Elareshi is an assistant professor in College of Communication and Media, Al Ain University of Science and Technology. His research interests include news consumption, young adults' media habits, new media, mobile phone use and satellite TV news. Email: mokhtar.elareshi@aau.ac.ae

Hatem Alsridi is an assistant professor in the Department of Media, Tourism and Arts at Bahrain University, Bahrain. His research interests include news media, Arab satellite TV channels, social media use.Email: halsridi@uob.edu.bh

Abdul-Karim Ziani is an associate professor in the Department of Media, Tourism and Arts at Bahrain University, Bahrain. Among his special areas of interest are international political communication, new media and politics and news coverage. Email: aziani@uob.edu.bh 


\section{REFERENCES}

Abdullah, S., \& Elareshi, M. (2015). Building narratives: A study of terrorism framing by Al Jazeera and Al Arabiya TV networks. Arab Media \& Society. Retrieved from http://www.academia.edu/download/38269568/20150625122309_Elareshi_Spring2015 Final.pdf

Al-Rawi, A. (2017). Assessing public sentiments and news preferences on Al Jazeera and Al Arabiya. International Communication Gazette, 79(1), 26-44. doi: $10.1177 / 1748048516642732$

Al-Rawi, A. (2019). Mobile news apps as sites of transnational ethnic mediascapes. The Journal of International Communication, 1-19. doi: 10.1080/13216597.2019.1678506

Al Jazeera. (2015). Egypt postpones retrial of Al Jazeera journalists.

Allcott, H., \& Gentzkow, M. (2017). Social media and fake news in the 2016 Election. Journal of Economic Perspectives, 31(2), 211-236. doi: 10.1257/jep.31.2.211

Arafa, M., \& Armstrong, C. (2015). Facebook to mobilize, twitter to coordinate protests, and YouTube to tell the world: New media, cmberactivism, and the Arab Spring. Journal of Global Initiatives, 10(1), 73-102.

Arthur, L. (1980). The secret side of war: Anglo-American and German intelligence in World War II. Journal of Political and Military Sociology, 8(1), 121.

Bar'el, Z. (2016). How Al Jazeera further damaged the fast-deteriorating Egypt-Qatar relationship. Haaretz. Retrieved on September 9, 2018, from https://www.haaretz.com/middle-eastnews/.premium-how-al-jazeera-further-damaged-egypt-qatar-relations-1.5472766

Barnes, A. (2013). Creating democrats? Testing the Arab Spring. Middle East Policy, 20(2), 55-72.

BBC. (2013). Egypt crisis: Al-Jazeera journalists arrested in Cairo. Retrieved on August 30, 2018, from https://www.bbc.co.uk/news/world-middle-east-25546389

Boyd-Barrett, O. (2016). Media imperialism. Los Angeles, CA: Sage Publications.

Boyd, D. (2017). The information war has begun. zephoria.org. Retrieved on November 18, 2019, from http://www.zephoria.org/thoughts/archives/2017/01/27/the-information-warhas-begun.html

Briant, E. (2018). Cambridge Analytica and SCL - How I peered inside the propaganda machine. The Conversation. Retrieved on August 29, 2018, from https://theconversation.com/cambridge-analytica-and-scl-how-i-peered-inside-thepropaganda-machine-94867

Brundidge, J., \& Rice, R. E. (2008). Political engagement online: Do the information rich get richer and the like-minded more similar? In, Routledge handbook of Internet politics (pp. 160172). London and New York: Routledge-Cavendish.

Buccianti, A., \& el-Richani, S. (2015). After the Arab uprisings: The prospects for a media that serves the public. BBC Media Action. Retrieved on September 20, 2016, from after-thearab-uprisings-sept-2015.pdf

Cairoscene. (2014). Egypt addicted to social media. Cairoscene.com. Retrieved on March 28, 2018, from http://www.cairoscene.com/LifeStyle/Egypt-Addicted-to-Social-Media

Calabresi, M. (2017). Inside Russia's social media war on America. time.com. Retrieved on January 14, 2020, fromhttps://time.com/4783932/inside-russia-social-media-war- america/ 
Carson, J. (2018, March 19). Fake news: What exactly is it-and how can you spot it?. The Telegraph.

Cherkaoui, T. (2014). Al Jazeera's changing editorial perspectives and the Saudi-Qatari relationship. The Political Economy of Communication, 2(1), 17-32.

Dennis, E., Martin, J., \& Hassan, F. (2019). Media use in the Middle East 2019: A seven-nation survey. Retrieved on December 20, 2019, from NorthWestern University in Qatar website: https://www.researchgate.net/publication/337674188\%0AMedia

Dennis, E., Martin, J., \& Wood, R. (2016). Media use in the Middle East: An six-nation survey. Retrieved on May 25, 2017, from Northwestern University-Qatar website: http://www.qatar.northwestern.edu/docs/publications/research-media-use/2016middle-east-media-use-report.pdf

EBU. (2018). "Fake news" and the information disorder. Retrieved on July 16, 2018, from European Broadcasting Union website: https://www.ebu.ch/publications

El-Nawawy, M. (2003). Why Al-Jazeera is the most popular network in the Arab world. Television Quarterly, 34(1), 10-15.

Elareshi, M. (2013). News consumption in Libya: A study of university student. Newcastle, UK: Cambridge Scholars Publishing.

Elareshi, M., \& Gunter, B. (2012a). Credibility of televised news in Libya: Are international news services trusted more than local news services? Journal of Middle East Media, 8(1).

Elareshi, M., \& Gunter, B. (2012b). Patterns of news media consumption among young people in Libya. Journal of African Media Studies, 4(2), 173-191.

Elshitawi, S. (2005). The role of the satellite channels in developing cultural awareness within Libya youth (Information Section, School of Arts and Information, Faculty of Higher Studies, Tripoli, Libya).

Elyachar, J. (2014). History and anthropology upending infrastructure: Tamarod, resistance, and agency after the January 25th Revolution in Egypt. History and Anthropology, 25(4), 452471. doi: $10.1080 / 02757206.2014 .930460$

Fahmy, S., \& Al-Emad, M. (2011). Al-Jazeera vs Al-Jazeera: A comparison of the network's Englishand Arabic-online coverage of the US/AI Qaeda conflict. International Communication Gazette, 73(3), 216-232. doi: 10.1177/1748048510393656

Farhi, P. (2014, January 5). Al Jazeera faces criticism in Egypt over its coverage of Muslim Brotherhood. Washington Post Newspaper.

Gunter, B. (1985). News sources and news awareness: A British survey. Journal of Broadcasting \& Electronic Media, 29(4), 397-406. doi: 10.1080/08838158509386595

Hargittai, E., \& Karaoglu, G. (2018). Biases of online political polls: Who participates? Socius: Sociological Research for a Dynamic World, 4, 1-7. doi: 10.1177/2378023118791080

Hjarvard, S. (2013). The mediatization of culture and society. New York: Routledge.

Hroub, K. (2011). Qatar's source of Arab springs. Project Syndicate. Retrieved on November 18, 2019, from https://www.project-syndicate.org/commentary/qatar-s-source-of-arabsprings?barrier=accesspaylog

Johnson, T., \& Fahmy, S. (2008). The CNN of the Arab world or a shill for terrorists? The International Communication Gazette, 70(5), 338-360. 
Johnson, T., \& Fahmy, S. (2010). Who is winning the hearts and minds of the Arab public? International Communication Research Journal, 45(1-2), 24-48.

Jones, M. (2019). Propaganda, fake news, and fake trends: The weaponization of Twitter bots in the Gulf crisis. International Journal of Communication, 13, 1389-1415. Retrieved from https://ijoc.org/index.php/ijoc/article/view/8994/2604

Khatib, L. (2012). Image politics in the Middle East: The role of the visual in political struggle. London: I.B Tauris Publishers.

Lynch, M. (2015). How the media trashed the transitions after the Arab spring. Journal of Democracy, 26(4), 90-99. doi: 10.1353/jod.2015.0070

Mejalli, W. (2019). Mediatization of politics analyzing Al-Jazeera Arabic online news articles during the development of war in Yemen.

Melican, D. B., \& Dixon, T. L. (2008). News on the net: Credibility, selective exposure, and racial prejudice. Communication Research, 35(2), 151-168.

Miladi, N. (2006). Satellite TV news and the Arab diaspora in Britain: Comparing Al-Jazeera, the BBC and CNN. Journal of Ethnic and Migration Studies, 32(6), 947-960. doi: 10.1080/13691830600761552

Monier, E. I., \& Ranko, A. (2013). The fall of the Muslim Brotherhood: Implications for Egypt. Middle East Policy, 20(4), 111-123. doi: 10.1111/mepo.12050

Rashdan, A. (2015). The "Sisification" of Egypt's media. Middle East Eye. Retrieved on September 3, 2018, from https://www.middleeasteye.net/columns/sisification-egypts-media1458142427

Ruggiero, T. E. (2000). Uses and gratifications theory in the 21st century. Mass Communication and Society, 3(1), 3-37. doi: 10.1207/S15327825MCS0301_02

Sadiku, M. N. O., Eze, T. P., \& Musa, S. M. (2018). Fake news and misinformation. International Journal of Advances in Scientific Research and Engineering, 4(5), 187-190. doi: 10.7324/IJASRE.2018.32728

Salem, F. (2017). The Arab social media report 2017: Social media and the Internet of things: Towards data-driven policymaking in the Arab world. Retrieved on December 20, 2017, from http://www.mbrsg.ae/getattachment/05534635-16f6-497a-b4a3d06f061bda0b/Arab-Social-Media-Report-2017

Salleh, Y. (2014, February 20). Activists who backed Mursi's fall turn against military. Reuters. Retrieved on December 20, 2019, from http://www.reuters.com/article/2014/02/20/usegypt-politics-tamarud-idUSBREA1J1E420140220

Sanyal, P. (2015). Egypt: Presidential elections, 2014. Contemporary Review of the Middle East Journal, 2(3), 289-307. doi: 10.1177/2347798915604923

Schapals, A. K. (2018). Fake news: Australian and British journalists' role perceptions in an era of "alternative facts." Journalism Practice, 12(8), 976-985. doi: 10.1080/17512786.2018.1511822

Shehabat, A. M. (2015). Arab 2.0 revolutions: Investigating social media networks during waves of the Egyptian political uprisings that occur between 2011, 2012 and 2013.

Shu, K., Sliva, A., Wang, S., Tang, J., \& Liu, H. (2017). Fake news detection on social media: A data mining perspective. ACM SIGKDD Explorations Newsletter, 19(1), 22-36. 
Silverman, C., \& Singer-Vine, J. (2016). Most Americans who see fake news believe it, new survey says. BuzzFeed. Retrieved on March 29, 2018, fro: https://www.buzzfeed.com/craigsilverman/fake-newssurvey?utm_term=.ngdXvb4bq\#.dxVO2BwBX

Statista. (2018). Number of Internet users in Egypt from 2013 to 2019. Statista. Retrieved September 11, 2018, from https://www.statista.com/statistics/462957/internet-usersegypt/

Sultan, N. (2013). Al Jazeera: Reflections on the Arab spring. Journal of Arabian Studies, 3(2), 249264. doi: 10.1080/21534764.2013.863821

Tabaar, A. (2013). Assessing (In)security after the Arab spring: The case of Egypt. Political Science and Politics, 46(4), 727-735. doi: 10.1017/S1049096513001261

Tambini, D. (2017). Fake news: Public policy responses. LSE Media Policy Project Series, Tambini, Damian and Goodman, Emma (eds.) (Media Policy Brief 20). London: The London School of Economics and Political Science.

Trager, E. (2017). The Muslim brotherhood is the root of the Qatar crisis. The Qatar Insider. Retrieved on September 9, 2018, from https://theqatarinsider.com/wpcontent/uploads/2017/07/The-Atlantic_The-Muslim-Brotherhood-Is-the-Root-of-theQatar-Crisis_2Jul...-1.pdf

Tsfati, Y., \& Cappella, J. (2003). Do people watch what they do not trust? Exploring the association between news media skepticism and exposure. Communication Research, 30(5), 504529. doi: $10.1177 / 0093650203253371$

Wahutu, J. S. (2019). Fake news and journalistic "rules of the game." African Journalism Studies, 1-14. doi: 10.1080/23743670.2019.1628794

Wardle, C. (2017). Fake news: It's complicated. First Draft News. Retrieved on August 27, 2018, from https://firstdraftnews.org/fake-news-complicated/

Williams, L. (2014). Inside Doha, at the heart of a GCC rift. The National. Retrieved on August 15, 2018, from https://www.thenational.ae/world/inside-doha-at-the-heart-of-a-gcc-rift1.320048

Yang, J., Barnidge, M., \& Rojas, H. (2017). The politics of "Unfriending": User filtration in response to political disagreement on social media. Computer in Human Behavior, 70, 22-29.

Zayani, M. (2005). The Al-Jazeera phenomenon: Critical perspectives on new Arab media. London: Pluto Press.

Ziani, A., \& Elareshi, M. (2016). Mobile phone and Internet usage in the GCC region: University students' perspectives. In B. Gunter, M. Elareshi, \& K. Al-Jaber (Eds.), Social media in the Arab world: Communication and public opinion in the Gulf States (pp. 91-115). London and New York: I.B Tauris Publishers.

Ziani, A., Elareshi, M., \& Al-Jaber, K. (2017). News media exposure and political communication among Libyan elites at the time of war. Mediterranean Journal of Social Sciences, 8(1), 330-339. doi: 10.5901/mjss.2017.v8n1p330

Ziani, A., Fahmy, S., Al-Jaber, K., \& Elareshi, M. (2014). Young adults' perceptions of satellite TV news services in Bahrain. Journal of Arab \& Muslim Media Research, 7(1), 3-20.

Zillmann, D., \& Bryant, J. (1985). Selective exposure to communication. Hillsdale, NJ: Lawrence Erlbaum. 


\section{SUPPLEMENT 1}

\section{PERCEPTION OF ONLINE NEWS QUESTIONNAIRE ${ }^{1}$}

THANK YOU for your assistance with this questionnaire. This study aims to assess Online viewing habits on academics, and to learn more about your perceptions towards online false news content. This is quite short questionnaire and your participation is COMPLETELY VOLUNTARY. We are grateful for your participation and request that you answer all the questions. PLEASE NOTE that no names are needed or any identification information anywhere on this questionnaire as all responses will remain anonymous.

Q1) What is your perception of news and information provided by Al-Jazeera.net in Arabic?
1. Very accurate [ ]
2. Less accurate [ ]
3. Don't know [ ]

Q2) How do you assess Al-Jazeera.net's coverage of the events in Egypt from June 30 (the start of demonstrations against Mohamed Mursi) and June 3, 2014 (the election of Abdel-Fattah El-sisi as president)
1. Very objective [ ] 2. Semi-
3. Don't know [ ]
4. Not objective [ ]
5. manipulating objective[ ] people []

Q3) Do you think that Al-Jazeera.net has different interest and agenda when provided news information about Egypt, what are the elements of the news that were used according to your opinion? (More than one option can be chosen)
1. Yes [ ]
2. No [ ]
3. Don't know [ ]

Q3.a) If you think that Al-Jazeera.net has any interest and agenda in Egypt, what are the types information used according to your opinion? (More than one option can be chosen)
1. Headings [ ]
2. Hyperlinks [ ]
3. Photos/images [ ]
4. Videos/clips [ ]
5. News stories [ ]
6. News sources [ ]
7. Comment on news [ ]
8. Social media [ ]
9. political figures [
10. Other (please specify)

Q4) What are the scopes used to post information by the network? (You can choose more than one option)
1. Political news [ ]
2. Security and
3. Financial
4. Social news [ ] 5. Cultural [ ]
6. Sports news [ ]
military news [ ]
news [ ]

Q5) To what extent do you agree or disagree, in your opinion, that Al-Jazeera.net posted some false news about the above mentioned period?

To support the MB party

SA

A

DK

D

SD

To affect the presidential elections

To manipulate the internal image of Egypt

To manipulate the external image of Egypt

Counterfeiting news is known on online media 
Perceptions of Online Academics' and Al-Jazeera.net's News Coverage of the Egyptian Political Transformation 20132014

Mokhtar Elareshi, Hatem Alsridi \& Abdul-Karim Ziani

Q6) What are the first three keywords/phrases that come to your mind that describe the online information delivered about Egypt?

1.

2.

3.

\begin{tabular}{|c|c|c|c|c|c|}
\hline \multicolumn{6}{|c|}{ Demographic information } \\
\hline Gender & M [ ] & $\mathrm{F}[\mathrm{]}$ & & & \\
\hline Age & 26-35 [ ] & $36-45$ [ ] & $46-55[$ ] & $56-65[$ ] & $>66[$ ] \\
\hline Education Rank & Professor [ ] & $\begin{array}{l}\text { Asso. } \\
\text { Professor [ ] }\end{array}$ & Ass. Professor [ ] & Lecturer [ ] & Ass. Lecturer [ ] \\
\hline Specialism & Journalism [ ] & $\begin{array}{l}\text { PR and } \\
\text { Ads [ ] }\end{array}$ & Radio \& TV [ ] & Online Media [ ] & \\
\hline Residence & Urban [ ] & Rural [ ] & & & \\
\hline
\end{tabular}

Thank you for your cooperation and assistance once again. 


\section{SUPPLEMENT 2}

\section{PERCEPTION OF ONLINE NEWS FOCUS GROUP ${ }^{1}$}

THANK YOU for your assistance with this interview. This study aims to assess Online viewing habits on academics, and to learn more about your perceptions towards online false news content. This is quite short discussion and your participation is COMPLETELY VOLUNTARY. We are grateful for your participation and request that you discuss all the questions with us. PLEASE NOTE that no names are needed or any identification information anywhere on this conversation as all responses will remain anonymous (coded).

\section{Procedures}

The interview technique with the discussion group aims to obtain information at different levels (political, cultural, social, economic, ideological, etc.) by collecting information related to academics' perceptions and experiences on the study topic.

\section{Measures and Discussion}

Through this qualitative analysis, using MAXQDA program, we compiled and analyzed the most discussed topics within the interview.

\section{Topics}

Four main axes were discussed:

The first axis: fake news including what is it, its goals, objectives and effects on the media credibility?

The second axis: Arabic e-journalism and misinformation including its uses, editorial policies and journalistic ethical standards.

The third axis: the relationship between Egypt and Al-Jazeera during 2013-2014. The fourth axis: the impact of Al-Jazeera's coverage on the political, security, economic and social situation in Egypt. 